\title{
A Bibliometric Analysis and Visualisation of Research Trends in Surface Coating of Hip Implant
}

\author{
Ripendeep Singh ${ }^{\mathrm{a}}$ \\ Department of Mechanical Engineering, Chandigarh University, Gharuan, Punjab,India. 140413
}

Article History: Received: 11 January 2021; Accepted: 27 February 2021; Published online: 5 April 2021

\begin{abstract}
Innovations and advances in material engineering and surface engineering play a key role in developing modern, safe, durable, and biocompatible implants. The bibliometric analysis had been conducted to understand the active authors, organizations, journals, and countries involved in the research domain of "surface coating of implants". All published articles related to "surface coating of implants" from "Scopus", were Journal of Bone and Joint Surgery and Biomaterials. The leading organization engaged in the research regarding surface coating of hip implants was the Royal National Orthopaedic Hospital NHS Trust of United Kingdom. The most active authors who had made valuable contributions related to the surface coating of implants were De Groot K and Goodman S.B.
\end{abstract}

Keywords: Surface coating, Hip implants, Material engineering, Bibliometric analysis, VOS viewer,

\section{Introduction}

The medical device to replace a missing or damaged biological structure is known as an implant. Different types of metals and materials are used to create implants and the most popularly used metals and alloys for bioimplants are stainless steel, cobalt-chromium alloy, and Titanium (Priyanka et al., 2014). Surface coating by using surface texturing, surface coating, bioactive glass/ bioglass coating, surface texturing, additive manufacturing, and many more technologies are available to enhance the performance of implants by ensuring safety, durability, and corrosion resistance. Moreover, surface conditioning offers better chemical stability and mechanical behavior than base material-based implants (Singha, Singh, and Sidhu, 2020).

Various types of surface treatments can be conducted on steel to improve its competency to be used as a material for hip-implants. However extensive corrosion of steel was observed in femoral hip prostheses with ages ranging from eight to twenty years after implantation (Musolino et al., 1996). Carbon/PEEK composite materials as an alternative for stainless steel/titanium hip prosthesis due to their comparative advantage of flatter load transfer and reduced stress levels (Rezaei et al., 2015).

Various types of surface treatments can be conducted on Titanium to improve its competency to be used as a material for bio-implants (Al-Radha et al., 2016). The surface properties and biocompatibility of Titanium-based hip implants can be improved by grafting the surface of selective laser melted (SLM) titanium alloy (Ti-6Al-4V) with poly (2-methacryloyloxyethyl phosphorylcholine) (PMPC) (Ghosh et al., 2018). Increased bone growth and reduced fibrous tissue in the porous coating of Titanium hip implants can be possible by Nanoscale surface coating by anodic oxidation of Titanium hip implants (Hall et al., 2017).

Surface treatments can be conducted on Zirconium implants to improve their competency to be used as a material for bio-implants (Gredes et al., 2014)(Berner et al., 2009)(Abras et al., 2020). There can be severe metallosis in case of wear of oxidized Zirconium in hip arthroplasty (Gkouliopoulou et al., 2016), similarly, the wear of Poly Ethylene is a concern in surface oxidized Zirconium hip implants (Jaffe et al., 2009). Even though Zirconium is a theoretically superior biomaterial, Zirconium is much less tolerant than Cobalt Chromium implants (Bonnheim et al., 2020).

This bibliometric analysis will be a useful platform for future researchers by realizing the top researchers, organizations, and countries involved in research regarding the surface treatment of hip-implants. This article is arranged into four sections. The first section is the introduction, followed by the discussion of the methodology by which the research was conducted. The third section deals with results and discussion. The fourth section deals with the conclusion. The following research objectives and research questions were framed for conducting bibliometric analysis systematically.

\subsection{Research Objectives}

a) To consolidate the literature regarding surface coating of hip implants

b) To find out the trends related to research in the surface coating of hip implants

\subsection{Research Questions}
a) Who are the active researchers working on the surface coating of hip implants?
b) Which are the main organizations and countries working on the surface coating of hip implants?
c) Which are the main journals related to the surface coating of hip implants? 


\section{Research Methodology}

Scopus files had been used for this article. For the article selection, the Boolean used was TITLE-ABS (surface coating implants) on 26/02/2021. All the tables in this paper were created by using Microsoft Excel and VOS Viewer. Grammarly was used for spelling and grammar checks. Mendeley was used for article review and citation. This paper had been inspired by bibliometric analysis in its presentation style, analysis, and methodology from the works (Farhat et al., 2013; Liao et al., 2016; Kolkailah et al., 2019; Rodríguez-Padial et al., 2019; Tran et al., 2019; Ullah et al., 2019; Shahid et al., 2020).

\section{Results and discussion}

\subsection{Results}

This first round of search produced an outcome of 430 documents, in eight languages, out of which 402 documents were in English. The classification of document categories is shown in Figure 1. For improving the quality of the analysis, we had selected only the peer-reviewed articles and all other documents had not been considered. Thus after using filters "Article" and "English" the second round search produced an outcome of 299 English articles (both open access and others) and had been used to conduct bibliometric analysis and visualization using VOS Viewer. The English research articles in this domain since 1975 had been shown in Figure 2.

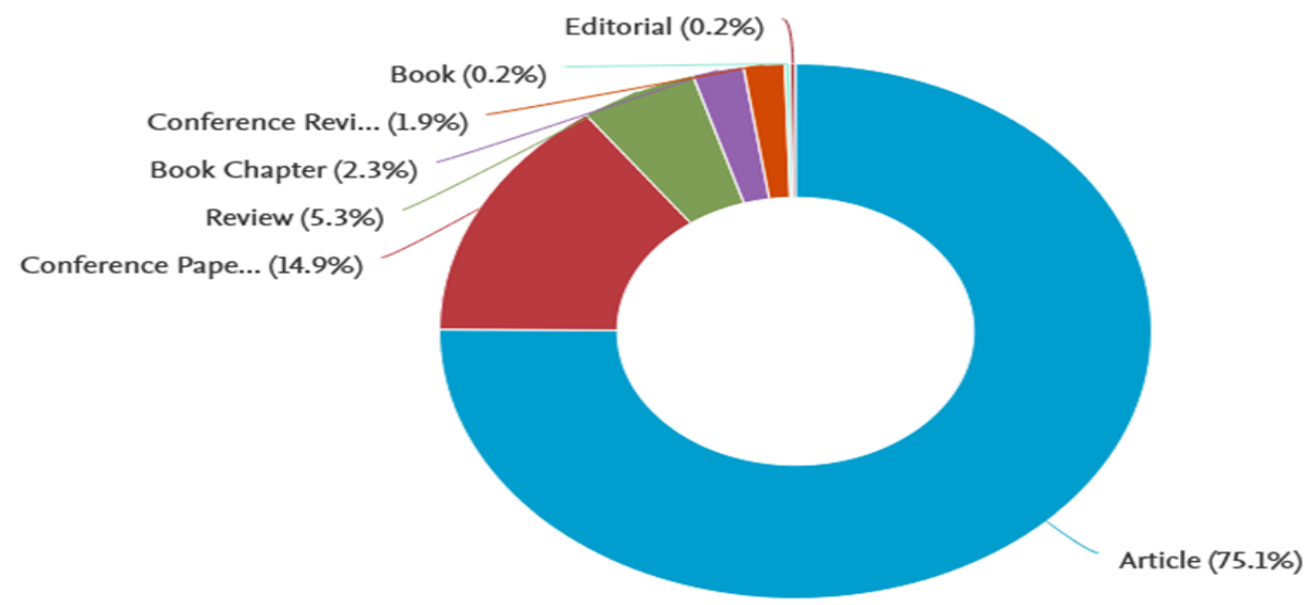

Figure 1: Classification of the documents on "surface coating of hip-implants", Source: www.scopus.com

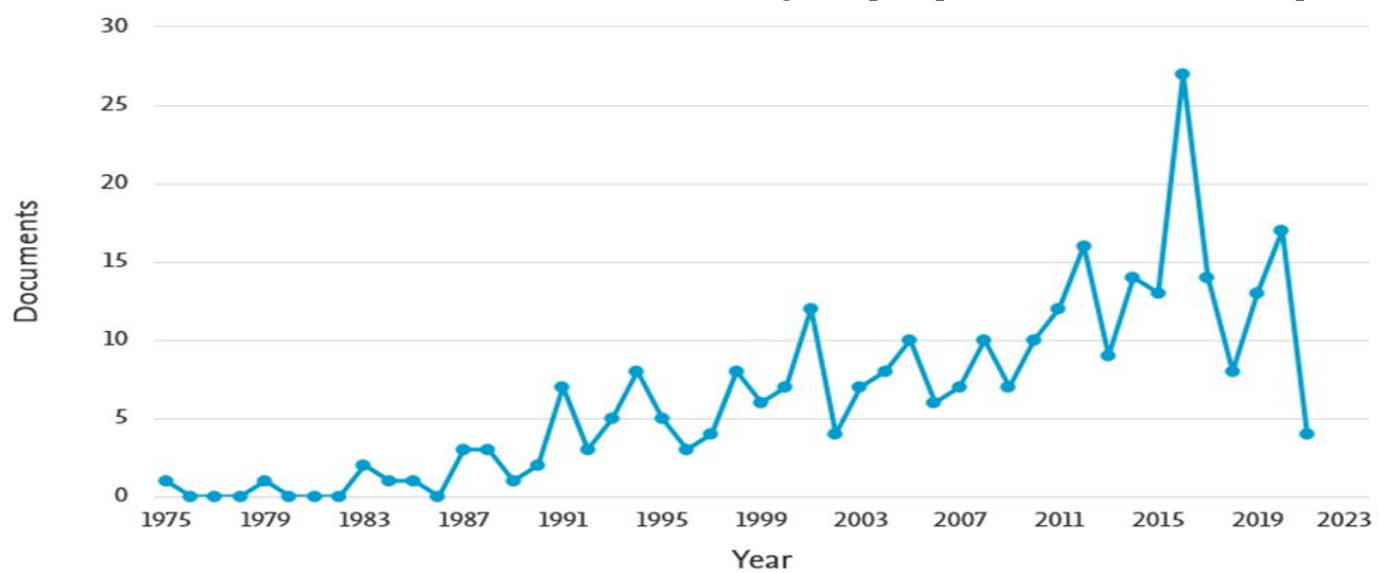

Figure 2: Period wise publication of articles, Source: WWW.scopus.com

Co-authorship analysis of top authors had been shown in figure 3. For a better presentation of the analysis, the parameters used were the minimum number of documents of an author as three and the minimum number of citations of authors as one. This combination plotted the map of 26 authors, in 17 clusters. The overlay visualization map of co-authorship analysis plotted in Figure 3, points out the major researchers with their strong co-authorship linkages and clusters involved. 


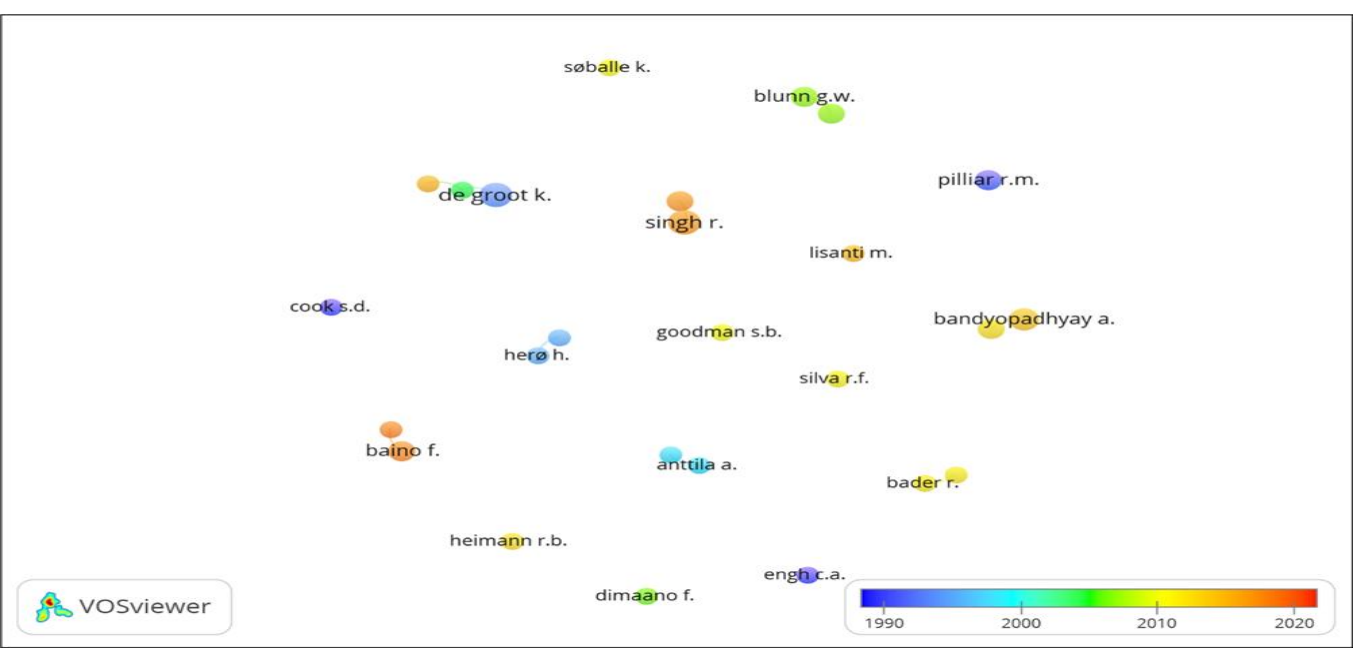

Figure 3: Co-authorship analysis on basis of authors

The citation analysis of top authors had been shown in table 1, along with co-authorship links. For the citation analysis, the parameters used were the minimum number of documents of an author as one and the minimum citations of an author as one.

Table 1: Highlights of most active authors

\begin{tabular}{|c|r|r|r|r|r|}
\hline Description & Authors & Documents & Citations & $\begin{array}{c}\text { Average } \\
\text { citations per } \\
\text { documents }\end{array}$ & $\begin{array}{c}\text { Link } \\
\text { strength }\end{array}$ \\
\hline $\begin{array}{l}\text { Authors with the } \\
\text { highest publication } \\
\text { and citations }\end{array}$ & De Groot K & 6 & 736 & 123 & 11 \\
\hline $\begin{array}{l}\text { Authors with the } \\
\text { highest co- } \\
\text { authorship links }\end{array}$ & Goodman S.B & 3 & 40 & & \\
\hline
\end{tabular}

In Co-occurrence analysis, we had used all keyword analyses, by keeping the minimum number of occurrences of a keyword as 40. This combination plotted the map of 26 thresholds, in two clusters. The overlay visualization of co-occurrence analysis of keywords has been shown in Figure 4.

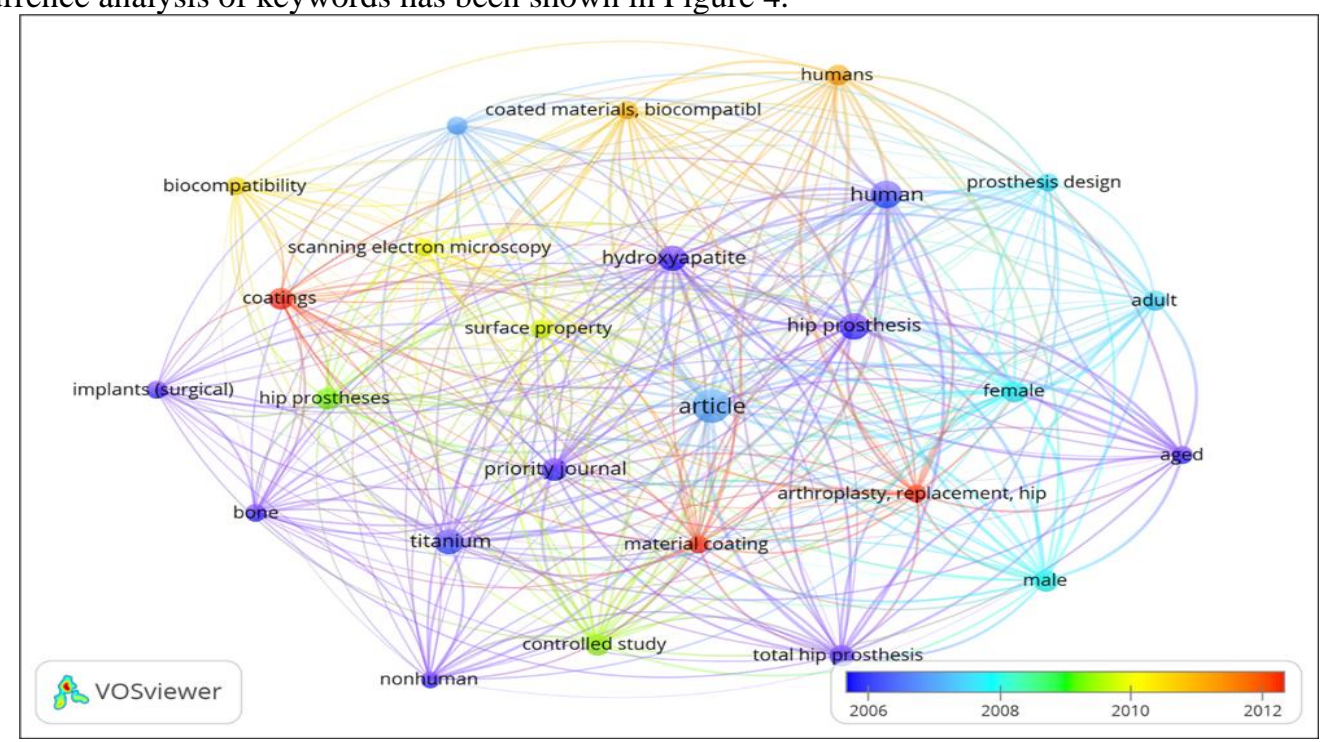

Figure 4: Co-occurrence analysis on basis of all keywords

The leading organizations engaged in research on "surface coating of hip implants" had been found out by the volume of publications and citation analysis, the parameters used are the minimum number of documents of an organization as one and the minimum number of citations of organizations as one. The leading organization in the research regarding "surface coating of hip implants", with the highest number of publications and citations, was the Royal National Orthopaedic Hospital NHS Trust, United Kingdom. (Refer to table 2).

Table 2: Highlights of the most active organization 


\begin{tabular}{|c|c|c|c|c|}
\hline Organizations & Country & s & Document & $\begin{array}{c}\text { Citatio } \\
\text { Average } \\
\text { Citations } \\
\text { per } \\
\text { document }\end{array}$ \\
\hline $\begin{array}{c}\text { Royal National Orthopaedic } \\
\text { Hospital NHS Trust }\end{array}$ & $\begin{array}{c}\text { United } \\
\text { Kingdom }\end{array}$ & 7 & 129 & 18.4 \\
\hline
\end{tabular}

Co-authorship analysis of the countries engaged in the research on "surface coating of hip implants" had been shown in Figure 5. The overlay visualization map of co-authorship analysis plotted in Figure 5, points out the main countries with their strong co-authorship linkages and clusters involved.

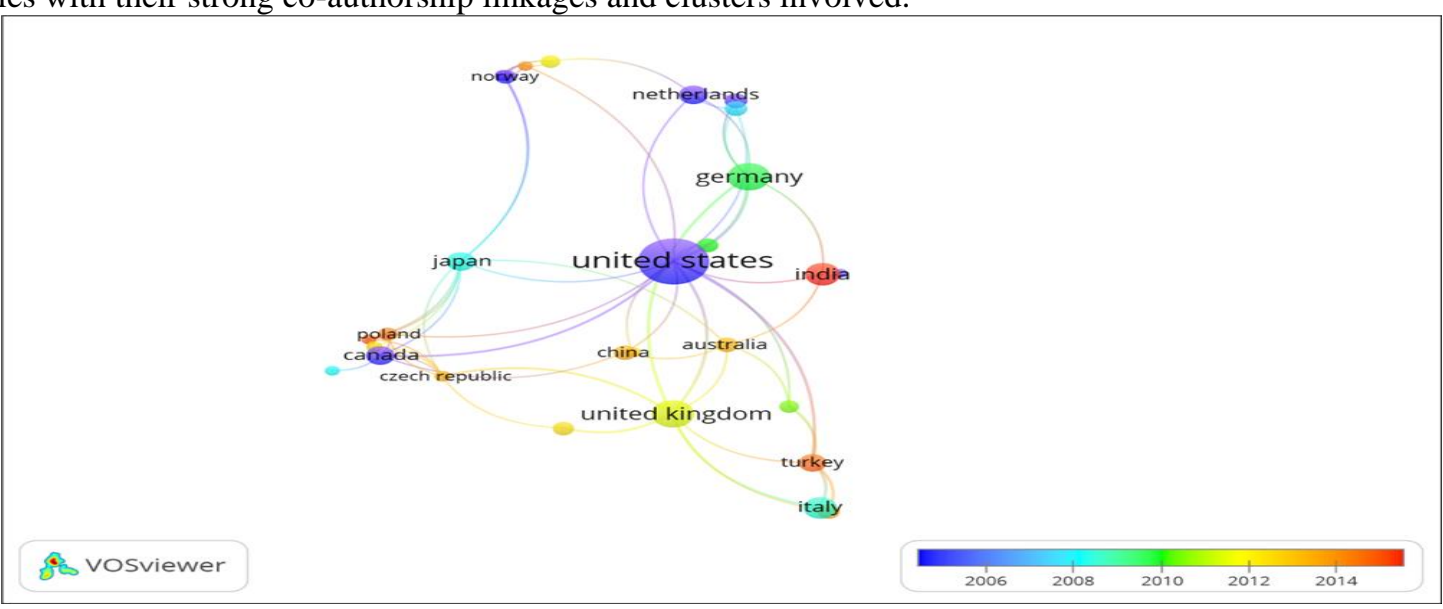

Figure 5: Co-authorship analysis on basis of countries

The citation analysis of top countries had been shown in table 3, along with co-authorship links. For the citation analysis, the parameters used were the minimum number of documents of a country as one and the minimum citations of the country as one.

Table 3: Highlights of Active Countries

\begin{tabular}{|c|c|c|r|r|}
\hline Description & Country & Document & Citation & Link strength \\
\hline $\begin{array}{c}\text { The country with the } \\
\text { highest publication, citations, } \\
\text { and co-authorship links }\end{array}$ & $\begin{array}{c}\text { United States of } \\
\text { America }\end{array}$ & 79 & 2291 & 21 \\
\hline
\end{tabular}

The most active country in this research domain was the United States of America, with the highest number of publications, citations, and co-authorship links respectively.

Link analysis and citation analysis were used to identify the most active journal in this research domain. We have taken the parameters of the minimum number of documents of a journal as one and the minimum number of citations of a journal as one for the link analysis and citation analysis. Highlights of the most active and relevant journals related to "surface coating of hip implants" are shown in table 4 . Table 4 shows the journal activity of this research domain through parameters of publication volume, citations, and co-authorship linkages.

Table 4: Analysis of journal activity

\begin{tabular}{|c|c|r|r|r|}
\hline Description & Journal details & Documents & Citations & $\begin{array}{c}\text { Co- } \\
\text { authorship }\end{array}$ \\
\hline $\begin{array}{l}\text { Journal with the } \\
\text { highest publications and } \\
\text { citations }\end{array}$ & Biomaterials & 13 & 1239 & 15 \\
\hline $\begin{array}{l}\text { Journal with the } \\
\text { highest co-authorship } \\
\text { links }\end{array}$ & $\begin{array}{c}\text { Journal of Bone } \\
\text { and Joint Surgery }\end{array}$ & 6 & 513 & 23 \\
\hline
\end{tabular}

From the above discussion regarding the bibliometric patterns in the research regarding surface coating of hip implants, this research had observed a gradual increase in research interest regarding surface coating of hip implants from the starting of the millennium and the momentum is going on positively. This points out the relevance and potential of this research domain (Refer to Figure 2). The most active authors in this research domain were De Groot K and Goodman S.B with the highest publication and co-authorship; and citations respectively (Refer to table 1). The overlay analysis of top countries researching surface coating of hip implants indicates that United States of America was the leading country relating to the highest number of publications, citations, and coauthorship links (Refer to figure 5). The top journals of this research domain were identified as the Biomaterials, and Journal of Bone and Joint Surgery. From these wide sources of information, researchers can focus on top 
journals where they can identify the most relevant and highly cited articles regarding the surface coating of hip implants.

\section{Conclusion}

Surface coating of hip implants was an interesting research domain and the most active journals related to this research domain were the Journal of Bone and Joint Surgery and Biomaterials. The leading organization engaged in the research regarding surface coating of hip implants was the Royal National Orthopaedic Hospital NHS Trust of United Kingdom. The most active authors who had made valuable contributions related to the surface coating of implants were De Groot K and Goodman S.B. This research domain offers a new avenue for researchers and future research can be on innovations in the surface coating of hip implants.

\section{References}

1. Biswas, A. et al. (2006) 'Laser surface nitriding of Ti-6Al-4V for bio-implant application', Trends in Biomaterials and Artificial Organs, 20(1), pp. 68-71. Available at: https://www.scopus.com/inward/record.uri?eid=2-s2.0$35648987155 \&$ partnerID=40\&md5=6593813558fa89eee $40891238 \mathrm{~d} 2 \mathrm{c} 0 \mathrm{~d} 82$.

2. Biswas, A. et al. (2007) 'Laser surface treatment of Ti-6Al-4V for bio-implant application', Lasers in Engineering, 17(1-2), pp. 59-73. Available at: https://www.scopus.com/inward/record.uri?eid=2-s2.034248217641\&partnerID=40\&md5=1a2989066074205064e3a1cf34599b2a.

3. Bose, S., Pathak, L. C. and Singh, R. (2018) 'Response of boride coating on the Ti-6Al-4V alloy to corrosion and fretting corrosion behavior in Ringer's solution for bio-implant application', Applied Surface Science. Elsevier B.V., 433, pp. 1158-1174. doi: 10.1016/j.apsusc.2017.09.223.

4. Farhat, T. et al. (2013) 'Research in congenital heart disease: A comparative bibliometric analysis between developing and developed countries', Pediatric Cardiology, 34(2), pp. 375-382. doi: 10.1007/s00246-0120466-6.

5. Förster, Y. et al. (2012) 'Surface coating of implants in long bone.' Biomatter, 2(3), pp. 149-157. doi: 10.4161/biom.21563.

6. $\mathrm{Gu}, \mathrm{M}$. et al. (2014) 'Is graphene a promising nano-material for promoting surface coating of implants or scaffold materials in bone tissue engineering?' Tissue Engineering - Part B: Reviews. Mary Ann Liebert Inc., 20(5), pp. 477-491. doi: 10.1089/ten.teb.2013.0638.

7. Hao, L. and Lawrence, J. (2006) Laser Surface Treatment of Bio-Implant Materials, Laser Surface Treatment of Bio-Implant Materials. John Wiley and Sons. doi: 10.1002/0470033975.

8. Jäger, M. (2018a) 'Surface coatings of implants. Part 1: Material technical and biological principles', Orthopade. Springer Verlag, 47(4), pp. 347-366. doi: 10.1007/s00132-018-3548-1.

9. Jäger, M. (2018b) 'Surface coatings of implants. Part 2: Clinical application', Orthopade. Springer Verlag, 47(5), pp. 445-458. doi: 10.1007/s00132-018-3560-5.

10. Kamachimudali, U., Sridhar, T. M., and Raj, B. (2003) 'Corrosion of bio-implants', Sadhana, 28(3), pp. 601-637. doi: 10.1007/BF02706450.

11. Kim, H.-K., Jang, J.-W. And Lee, C.-H. (2004) 'Surface coating of implant materials and its effect on attachment and proliferation of bone cells', Journal of Materials Science: Materials in Medicine, 15(7), pp. 825-830. doi: 10.1023/B:JMSM.0000032824.62866.a1.

12. Kolkailah, A. A. et al. (2019) 'Bibliometric Analysis of the Top 100 Most Cited Articles in the First 50 Years of Heart Transplantation', American Journal of Cardiology. Elsevier Inc., 123(1), pp. 175-186. doi: 10.1016/j.amjcard.2018.09.010.

13. Kumar, A. et al. (2014) 'Laser surface cladding of Ti-6Al-4V on AISI 316L stainless steel for bio-implant application', Lasers in Engineering. Old City Publishing, 28(1-2), pp. 11-33. Available at: https://www.scopus.com/inward/record.uri?eid=2-s2.0-

14. 84901951631\&partnerID=40\&md5=cae38b128d70e5d9e11821788ab6b17a.

15. Liao, J. et al. (2016) 'the most cited articles in coronary heart disease: A bibliometric analysis between 1970 and 2015', International Journal of Cardiology. Elsevier Ireland Ltd, 222, pp. 1049-1052. doi: 10.1016/j.ijcard.2016.08.002.

16. Majumdar, J. D. et al. (2018) 'Laser Surface Melting of AISI 316L Stainless Steel for Bio-implant Application', Proceedings of the National Academy of Sciences India Section A - Physical Sciences. Springer, 88(3), pp. 387-403. doi: 10.1007/s40010-018-0524-4.

17. Paital, S. R. and Dahotre, N. B. (2009) 'Calcium phosphate coatings for bio-implant applications: Materials, performance factors, and methodologies', Materials Science and Engineering R: Reports, 66(13), pp. 1-70. doi: 10.1016/j.mser.2009.05.001.

18. Patel, S. B. et al. (2014) 'Enhancing surface characteristics of Ti-6Al-4V for bio-implants using integrated anodization and thermal oxidation', Journal of Materials Chemistry B. Royal Society of Chemistry, 2(23), pp. 3597-3608. doi: 10.1039/c3tb21731k.

19. Priyanka, P. et al. (2014) Role of nanogrooves on the performance of ultra-fine grained titanium as a bioimplant, Advanced Nanomaterials: Synthesis, Properties, and Applications. Apple Academic Press. doi: 10.1201/b16966. 
20. Ralls, A. et al. (2020) 'Material Design and Surface Engineering for Bio-implants', JOM, 72(2), pp. 684696. doi: 10.1007/s11837-019-03687-2.

21. Rodríguez-Padial, L. et al. (2019) 'Trends and Bibliometric Impact of Research Grants of the Spanish Society of Cardiology/Spanish Heart Foundation (2007-2012) [Evolución e impacto bibliométrico de las becas de la Sociedad Española de Cardiología/Fundación Española del Corazón en el periodo 2007-2012]', Revista Espanola de Cardiologia. Ediciones Doyma, S.L., 72(12), pp. 1012-1019. doi: 10.1016/j.recesp.2018.08.013.

22. Seitz, B. S. et al. (2018) 'Nanoparticles and Liposomes for the Surface Coating of Implants: A Comparative Study of Spraying and Dipping Techniques', Physica Status Solidi (A) Applications and Materials Science. Wiley-VCH Verlag, 215(15). doi: 10.1002/pssa.201700847.

23. Shahid, I. et al. (2020) 'Characteristics of highly cited articles in heart failure: A bibliometric analyses, Future Cardiology. Future Medicine Ltd., 16(3), pp. 189-197. doi: 10.2217/fca-2019-0016.

24. Singha, B., Singh, G. and Sidhu, B. S. (2020) 'Current Trends in Bio-I mplants ' Research', The Research Publication, 7(2), pp. 57-59.

25. Sodhi, G. P. S., and Singh, H. (2018) 'Development of corrosion-resistant surfaces via friction stir processing for bio implant applications', in IOP Conference Series: Materials Science and Engineering. Institute of Physics Publishing. doi: 10.1088/1757-899X/284/1/012026.

26. Stanford, C. M. (2002) 'Surface coatings of implants', Oral and Maxillofacial Surgery Clinics of North America. W.B. Saunders, 14(1), pp. 39-51. doi: 10.1016/S1042-3699(02)00016-X.

27. Ting, M. et al. (2017) 'Classification and Effects of Implant Surface Coating on the Bone: Human CellBased In Vitro Studies', Journal of Oral Implantology, 43(1), pp. 58-83. doi: 10.1563/aaid-joi-D-1600079.

28. Tran, B. X. et al. (2019) 'The current research landscape of the application of artificial intelligence in managing cerebrovascular and heart diseases: A bibliometric and content analysis', International Journal of Environmental Research and Public Health. MDPI AG, 16(15). doi: 10.3390/ijerph16152699.

29. Ullah, S. et al. (2019) 'Publication trends of Pakistan Heart Journal: A bibliometric study', Library Philosophy and Practice. University of Idaho Library, 2019. Available at: https://www.scopus.com/inward/record.uri?eid=2-s2.0$85072911351 \&$ partnerID=40\&md5=c7b4ec3c78fbd1fed8e2e7890fdef688.

30. Ye, J. et al. (2019) 'Cicada and catkin inspired dual biomimetic antibacterial structure for the surface coating of implant material', Biomaterials Science. Royal Society of Chemistry, 7(7), pp. 2826-2832. doi: $10.1039 / \mathrm{c} 9 \mathrm{bm} 00082 \mathrm{~h}$ 